\title{
Acinetobacter baumannii in Localised Cutaneous Mycobacteriosis in Falcons
}

\author{
Margit Gabriele Muller, ${ }^{1}$ Ancy Rajeev George, ${ }^{1}$ and Julia Walochnik ${ }^{2}$ \\ ${ }^{1}$ Abu Dhabi Falcon Hospital, EAD, P.O. Box 45553, Abu Dhabi, UAE \\ ${ }^{2}$ Abteilung Für Medizinische Parasitologie, Klinisches Institut für Hygiene und Medizinische Mikrobiologie, \\ Medizinische Universität Wien, Kinderspitalgasse 15, 1095 Vienna, Austria
}

Correspondence should be addressed to Margit Gabriele Muller, vet_uae@hotmail.com

Received 18 April 2010; Revised 29 June 2010; Accepted 21 July 2010

Academic Editor: Andrew Potter

Copyright (c) 2010 Margit Gabriele Muller et al. This is an open access article distributed under the Creative Commons Attribution License, which permits unrestricted use, distribution, and reproduction in any medium, provided the original work is properly cited.

Between May 2007 and April 2009, 29 falcons with identically localized, yellowish discolored cutaneous lesions in the thigh and lateral body wall region were presented at Abu Dhabi Falcon Hospital. Out of 18 falcons integrated in this study, 16 tested positive to Mycobacterium. avium complex. The 2 negative falcons tested positive in the Mycobacterium genus PCR. Moreover, 1 falcon tested positive to M. avium. paratuberculosis in tissue samples by PCR. In all cases, blood and fecal samples tested negative. In the acid-fast stain, all samples showed the for mycobacteriosis typical rods. Moreover, in 13 samples Acinetobacter baumannii was detected by PCR and proven by DNA sequencing. Clinical features included highly elevated WBCs, heterophilia, lymphocytopenia, monocytosis, severe anemia and weight loss. A. baumannii, a gram-negative bacillus with the ability to integrate foreign DNA, has emerged as one of the major multidrug resistant bacteria. In veterinary medicine, it has so far been detected in dogs, cats, horses and wild birds. To the authors' knowledge, this is the first report of an A. baumannii infection in falcons and of a veterinary Mycobacterium-Acinetobacter coinfection.

\section{Introduction}

The genus Acinetobacter comprises strictly aerobic, gramnegative and nonfermentative bacteria belonging to the family Moxarellaceae. They are widely distributed in the environment as well as in hospitals, where they can survive on moist or dry surfaces for long periods of time [1] on dry surfaces [2]. Acinetobacter can also be found in soil and constitutes as one of the predominant organisms in water [3].

A. baumannii is the most commonly found Acinetobacter species in humans and has emerged as multidrug resistant [1]. Moreover, it has evolved as one of the most important nosocomial pathogens in the past decade [4] particularly in immunosuppressed patients [1]. A. baumannii can affect different organs causing pneumonia, meningitis, septicemia and urinary tract [5] and skin infections [4]. However, it is still not entirely clear how A. baumannii is transmitted. Its "success" as an emerging pathogen might be based on its ability to integrate large amounts of foreign DNA into its genome, located as significant fractions of ORFs on 28 putative alien islands [5]. Risk factors such as underlying diseases or infections of the affected patient, hospitalization, cephalosporin treatment, and medical procedures may pave the way for A. baumannii infections [4]. Antimicrobial treatment can be considered as a predisposing factor for A. baumannii infections [4]. Between January 2002 and August 2004, A. baumannii infections were diagnosed when "military health officials identified 102 patients with blood cultures that grew A. baumannii at military medical facilities treating service members injured in Afghanistan and the Iraq/Kuwait region" (CDC, 2004). A potential environmental contamination of traumatic injuries might have been an influencing factor (CDC, 2004). Moreover, A. baumannii is known to survive for long periods of time.

In contrast to A. baumannii infections, mycobacteriosis is well described in birds and mainly caused by Mycobacterium avium and Mycobacterium genavense. Both pathogens are excreted with the feces [6, 7] and affect mainly hepatic and 
gastrointestinal organ systems [8]. Water, soil, plants and other environmental sources serve as reservoirs for the $M$. avium complex [9]. M. avium can be transmitted from birds to immunosuppressed humans like AIDS patients [9] and has been isolated from cutaneous tuberculosis lesions in humans [10].

General symptoms of mycobacteriosis include weight loss, polyuria, coelomic distention, and diarrhea. Rarely cutaneous masses and lameness can be found [7]. Skin granulomas caused mainly by $M$. genavense can be flaky, dry, or raised ulcers and are usually not painful [11]. Granulomatous dermatitis in psittacines can be caused by $M$. genavense, too [12].

\section{Material and Methods}

2.1. Clinical Investigation. From May 2007 to April 2009, a total number of 29 falcons, among them 19 Gyr-Peregrine hybrid falcons, 9 Gyr-Saker hybrid falcons, and 1 peregrine falcon, were presented at the Abu Dhabi Falcon Hospital. 26 falcons were females and 2 Gyr-Peregrine hybrid falcons and 1 Gyr-Saker hybrid falcons were males. All falcons belonged to different owners and were bred by different breeders in UAE and Europe. The falcons' age was between 1 and 3 years and all were used for hunting.

For this study, a group of 18 falcons was selected for which all below-mentioned tests could be performed. For the other 11 falcons, most of the tests were performed but not all tests could be done. Therefore, those falcons were excluded from the study. Out of the 18 falcons, 16 falcons had repeatedly visited the hospital. For 2 falcons, it was the first visit. In most falcons, a time span of at least 3-5 months between being diagnosed without abnormality and the manifestation of visible lesions could be observed. One falcon from the UK came from a breeding center where previously another falcon had been diagnosed with mycobacteriosis granuloma. All 18 falcons were either diagnosed with unspecific symptoms, including anorexia, weight loss, and not flying well or presented only for general examination. However, all falcons had cutaneous yellowishcolored lesions. Those lesions were located on the right and left lower thoracical body wall and abdominal body walls as well as the inside of both thighs. The lesions were opened surgically and tissue material was extracted for examination. Then the lesions were sutured with 3-0 Ethilon* (Ethicon, Johnson and Johnson, Belgium).

\subsection{Laboratory Diagnostics}

2.2.1. Blood Examination. Blood samples for hematological and biochemical examination were taken from the left or right V. cutanea ulnaris superficialis and processed within maximum 30 minutes in the laboratory. The blood hematology was performed according to the protocol of Muller et al. [13]. The ACE-Wasserman biochemistry analyser (Schiaparelli Biosystems) was used to measure the blood chemistry parameters by photometry. In 10 falcons, blood was taken 1-3 times. In 8 falcons, the blood sampling was repeated 3 up to 8 times every 3 to 8 days. The blood sampling of one Gyr-peregrine hybrid falcon was not possible due to poor condition of the bird.

2.2.2. Acid-Fast Bacilli Staining. Acid-fast bacilli staining with Ziehl-Neelsen (ZN) stain (ZN-TB Stain Kit (AFB Stain), GCC Diagnostics, Flintshire, UK) was performed for the biopsied tissues and fecal samples of all falcons tested.

2.2.3. Molecular Analysis. The tissues as well as blood and fecal samples were examined by PCR. DNA was extracted from fresh tissue and one blood sample using DNA-SorbA DNA Extraction Kit (Sacace Biotechnologies Srl, Caserta, Italy) as per the manufacturers' instruction followed by amplification of the Mycobacterium genus DNA using the Mycobacterium genus PCR Kit including 4 different primer pairs for M. genus, M. tuberculosis, M. avium paratuberculosis, and M. avium avium (Genekam Biotechnology, AG, Germany). The PCR was performed in a final volume of $20 \mu \mathrm{L}$. The reaction mixture was then subjected to 38 cycles of amplification. (Denaturation at $94^{\circ} \mathrm{C}$ for 30 seconds, annealing at $65^{\circ} \mathrm{C}$ for 60 seconds, and extension at $72^{\circ} \mathrm{C}$ for 120 seconds). After PCR amplification, a $10 \mu \mathrm{L}$ aliquot of the PCR products was electrophoresed for 1 hour through a $2 \%$ agarose gel. The target band of $236 \mathrm{bp}$ ( of Mycobacterium genus DNA) was visualized under UV illumination.

In order to clarify why the Mycobacterium-specific PCR was negative in most samples despite a clinically suspected mycobacteriosis and to identify the mycobacterial species, a seminested PCR designed for diagnosis of avian mycobacteriosis [14] was performed with all samples. In brief, for the first round primers 246 and 247 were used to amplify an approximately $600 \mathrm{bp}$, and the amplicon was then subjected to a second round using the p7 and the 247 primers and resulting in a $\sim 550 \mathrm{bp}$ fragment of the first amplicon. Amplification of the respective fragments was visualized by ethidium-bromide in a $2 \%$ agarose gel electrophoresis. For identification, the resulting amplicons were subjected to DNA sequencing. Sequencing was carried out in a 310 ABI PRISM automated sequencer (Applied Biosystems, Langen, Germany) and sequences were compared to sequences available at GenBank using BLAST search [15]. Moreover, samples (except samples 3 and 10, from which no material was left) were screened with a universal bacterial PCR using the 16S_for and 16S_rev primers [16] and as sequencing of the respective amplicons revealed highest identity of the sequences to Acinetobacter baumannii, all positive samples were screened with a PCR specific for $A$. baumannii [17] amplifying the internal transcribed spacer (ITS) region. Again, amplification was visualized by $2 \%$ agarose gelelectrophoresis and amplicons were excised from the gels and subjected to DNA sequencing.

\section{Results}

3.1. Clinical Inspection. Out of 18 falcons, a total number of 26 cutaneous lesions were found. $94 \%$ of the falcons had a lesion on the left and/or right body wall, whereas $50 \%$ 
TABLE 1: Location and diameter of cutaneous lesions.

\begin{tabular}{|c|c|c|c|c|}
\hline S. No & $\begin{array}{l}\text { Lesion on left lower thoracical } \\
\text { and abdominal wall }\end{array}$ & $\begin{array}{c}\text { Lesion on right lower thoracical } \\
\text { and abdominal wall }\end{array}$ & $\begin{array}{l}\text { Lesion on medial part of } \\
\text { left thigh }\end{array}$ & $\begin{array}{l}\text { Lesion on medial } \\
\text { part of right thigh }\end{array}$ \\
\hline 1 & $0.5-1 \mathrm{~cm}$ & $0.5-1 \mathrm{~cm}$ & & \\
\hline 2 & & & $2.1-5 \mathrm{~cm}$ & \\
\hline 3 & $0.5-1 \mathrm{~cm}$ & $0.5-1 \mathrm{~cm}$ & $1.1-2 \mathrm{~cm}$ & $1.1-2 \mathrm{~cm}$ \\
\hline 4 & $1.1-2 \mathrm{~cm}$ & & & \\
\hline 5 & & larger than $5 \mathrm{~cm}$ & & larger than $5 \mathrm{~cm}$ \\
\hline 6 & $2.1-5 \mathrm{~cm}$ & & & \\
\hline 7 & $2.1-5 \mathrm{~cm}$ & & & \\
\hline 8 & & & $1.1-2 \mathrm{~cm}$ & \\
\hline 9 & & & & $0.5-1 \mathrm{~cm}$ \\
\hline 10 & $1.1-2 \mathrm{~cm}$ & & & \\
\hline 11 & $2.1-5 \mathrm{~cm}$ & & $2.1-5 \mathrm{~cm}$ & \\
\hline 12 & $2.1-5 \mathrm{~cm}$ & $2.1-5 \mathrm{~cm}$ & & \\
\hline 13 & $2.1-5 \mathrm{~cm}$ & & & \\
\hline 14 & $2.1-5 \mathrm{~cm}$ & & & \\
\hline 15 & & & $1.1-2 \mathrm{~cm}$ & \\
\hline 16 & & & & $1.1-2 \mathrm{~cm}$ \\
\hline 17 & $2.1-5 \mathrm{~cm}$ & $2.1-5 \mathrm{~cm}$ & & \\
\hline 18 & & larger than $5 \mathrm{~cm}$ & & \\
\hline
\end{tabular}

showed lesions on either or both thigh inside areas (Table 1). Except for two falcons treated, all other falcons died or were euthanized as per request of their owners.

In $39 \%$ of the falcons, no other microorganisms were detected. In the remaining $61 \%$, more than one infection was found. Among these, $37 \%$ of falcons were identified with aspergillosis. $6 \%$ showed hepatopathic lesions and in $18 \%$, hepatomegaly was detected. Moreover, $6 \%$ suffered from pseudomoniasis. Airsacculitis was detected in $6 \%$ and infestation with Serratospiculum seurati worms in another $6 \%$ of falcons.

3.2. Blood Examination. The blood examinations were separated according to the hybrid species. Moreover, the mean values for hematology and blood biochemistry of all falcons in the study were established. Furthermore, the blood parameters' mean values of falcons with mycobacteriosis combined with $A$. baumannii infection were evaluated (Tables 2 and 3 ). The established values were compared to reference values for hematology $[13,18]$ and biochemistry [18].

3.3. Ziehl-Neelsen Staining. In the Ziehl-Neelsen (ZN) stain, acid-fast bacilli were detected in the cytological squash of biopsied cutaneous tissues as well as fecal material of all falcons tested. In $50 \%$, the stain revealed acid-fast bacilli covering $2 / 3$ or more of each examined microscopic field (Figure 1). In the remaining cases, $1 / 3$ to $2 / 3$ of the microscopic slides were covered with acid-fast bacilli in the

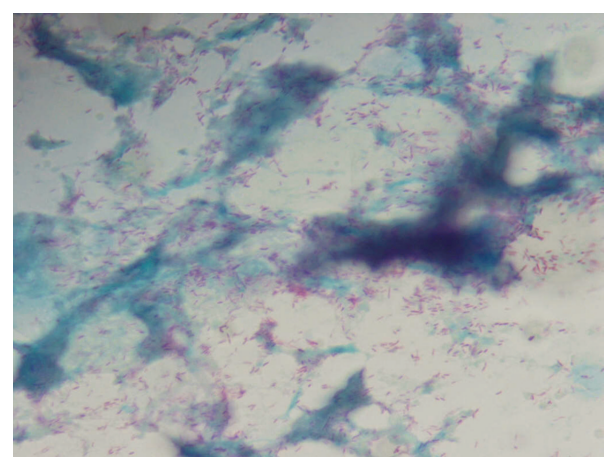

FIGURE 1: Acid fast organisms stain in bright pink color.

ZN stain. Only in $11 \%$, acid-fast bacilli were additionally identified in the feces material.

3.4. Molecular Results. Molecular results are summarised in Table 4. In the Mycobacterium genus PCR, all samples except samples 8, 9, 10, and 11 were positive. The Mycobacterium avium subspecies paratuberculosis PCR was positive in one case (sample 3). Samples were then also screened with a seminested diagnostic PCR for avian mycobacteriosis. However, unfortunately not of all samples enough material was left, so this PCR could only be conducted with 20 samples as sample 9 , and 18 was tested twice. Of these, $80 \%$ tested positive in the seminested PCR. Sequencing of the 
TABle 2: Mean of hematology results of Gyr-Saker and Gyr-Peregrine hybrid falcons tested positive for A. baumannii and mycobacteriosis.

\begin{tabular}{|c|c|c|c|c|}
\hline Parameters & $\begin{array}{l}\text { Gyr-Saker with } \\
\text { Mycobacteriosis }\end{array}$ & Gyr-Saker reference values & $\begin{array}{c}\text { Gyr-Peregrine with A. } \\
\text { baumannii + Mycobacteriosis }\end{array}$ & $\begin{array}{l}\text { Gyr-Peregrine } \\
\text { reference values }\end{array}$ \\
\hline & $n=2$ & & $n=9$ & \\
\hline $\mathrm{RBC}\left(\times 10^{12} / \mathrm{l}\right)$ & 2.15 & $2.18-2.48$ & 2.02 & $2.13-2.65$ \\
\hline $\mathrm{Hb}(\mathrm{g} / \mathrm{dl})$ & 12.60 & $16.23-19.23$ & 12.23 & $16.33-19.47$ \\
\hline Hct $\%$ & 38.10 & $46.91-56.23$ & 34.10 & $47.25-56.75$ \\
\hline $\operatorname{MCV}(\mathrm{fl})$ & 166.45 & 200.29-243.49 & 186.62 & $194.32-245.08$ \\
\hline $\mathrm{MCH}(\mathrm{pg})$ & 58.40 & $69.41-83.07$ & 67.48 & $67.14-84.04$ \\
\hline $\mathrm{MCHC}(\mathrm{g} / \mathrm{dl})$ & 35.10 & $32.85-35.99$ & 36.51 & $32.95-35.91$ \\
\hline $\mathrm{WBC}\left(\times 10^{9} / 1\right)$ & 29.70 & $5.28-9.72$ & 31.53 & $5.28-9.82$ \\
\hline Heterophils\% & 71.00 & $46.02-53.78$ & 72.90 & $46.41-53.41$ \\
\hline Lymphocytes\% & 19.90 & $41.20-47.02$ & 22.14 & $40.82-47.54$ \\
\hline Monocytes\% & 3.00 & $2.84-6.00$ & 3.31 & $2.77-6.03$ \\
\hline Eosinophils\% & 1.00 & $0.37-2.21$ & 1.26 & $0.29-2.45$ \\
\hline Basophils\% & 0.50 & $0.25-0.55$ & 0.56 & $0-0$ \\
\hline
\end{tabular}

TABle 3: Mean of blood biochemistry results of Gyr-Saker and Gyr-Peregrine hybrid falcons tested positive for A. baumannii and mycobacteriosis.

\begin{tabular}{|c|c|c|c|c|}
\hline Parameters & $\begin{array}{c}\text { Gyr-Sakerwith A. } \\
\text { baumannii }+ \\
\text { Mycobacteriosis }\end{array}$ & Gyr-Saker reference values & $\begin{array}{c}\text { Gyr-Peregrinewith A. } \\
\text { baumannii }+ \\
\text { Mycobacteriosis }\end{array}$ & $\begin{array}{l}\text { Gyr-Peregrine reference } \\
\text { values }\end{array}$ \\
\hline & $n=2$ & & $n=9$ & \\
\hline GGT (U/L) & 13.6 & $5.5-11.5$ & 10.3 & $6.0-12.0$ \\
\hline $\operatorname{AST}(\mathrm{U} / \mathrm{L})$ & 103.9 & $45.0-122.3$ & 138.1 & $47.0-110.0$ \\
\hline $\operatorname{ALT}(\mathrm{U} / \mathrm{L})$ & 122.8 & $37.2-91.0$ & 116.6 & $44.9-73.5$ \\
\hline $\mathrm{TP}(\mathrm{g} / \mathrm{dl})$ & 3.7 & $2.2-3.4$ & 3.4 & $2.15-3.35$ \\
\hline $\operatorname{ALB}(\mathrm{g} / \mathrm{dl})$ & 1.3 & $0.9-1.2$ & 1.1 & $0.73-1.35$ \\
\hline $\mathrm{LDH}(\mathrm{U} / \mathrm{L})$ & 2825.9 & $788.8-1493.3$ & 2811.5 & $802.0-1457.0$ \\
\hline $\mathrm{CK}(\mathrm{U} / \mathrm{L})$ & 466.9 & $312.3-681.3$ & 740 & $341.0-668.7$ \\
\hline $\mathrm{UA}(\mathrm{mg} / \mathrm{ml})$ & 5.9 & $3.4-7.5$ & 9.5 & $3.60-7.0$ \\
\hline UREA (mg/ml) & 17.6 & $6.4-20.1$ & 29.1 & $7.0-17.0$ \\
\hline CHOL (mg/ml) & 105.3 & $159.0-267.0$ & 144.8 & $167.0-267.0$ \\
\hline $\operatorname{ALP}(\mathrm{U} / \mathrm{L})$ & 227.8 & - & 169.2 & - \\
\hline AMYL (U/L) & 159.5 & - & 857.6 & - \\
\hline
\end{tabular}

amplicons revealed $100 \%$ sequence identity to the $M$. avium complex (MOC) in all positive cases. Moreover, 60\% were positive in the specific A. baumannii PCR.

3.5. Therapeutic Results. Both falcons treated were administered by a monotherapy of rifampicin $30 \mathrm{mg} / \mathrm{kg}$ once a day. One falcon was treated for 68 days and recovered. Subsequent PCR tests for Mycobacterium sp. were negative. The other falcon was treated for 45 days. It returned after 39 days in apparently good condition and without visible granulomatous lesions with intralesional mycobacteria, however, no further PCR testing could be performed.

\section{Discussion}

Between May 2007 and April 2009, mycobacteriosis was detected in 18 falcons. 16 of them tested positive in the seminested mycobacteria PCR. Moreover, the 2 negative samples tested positive for $M$. genus PCR. Furthermore, 2 samples were additionally tested positive for M. avium and one for M. avium paratuberculosis. These findings stand in sharp contrast to a study on pet birds where the causative agents were mainly $M$. genavense and only in one case $M$. avium [14] In the vast majority of cases (16 falcons), the time frame of the examination of clinically healthy falcons until 
TABle 4: Diagnostic results with Polymerase Chain reaction of positive cases in the second test run.

\begin{tabular}{|c|c|c|c|c|c|}
\hline S. No. & Mycobacterium genus & $\begin{array}{l}\text { Mycobacteria } \\
\text { seminested }\end{array}$ & $\begin{array}{c}\text { Mycobacterium avium } \\
\text { avium }\end{array}$ & $\begin{array}{c}\text { Mycobacterium avium } \\
\text { tuberculosis }\end{array}$ & $\begin{array}{c}\text { Acinetobacter } \\
\text { baumannii }\end{array}$ \\
\hline 1 & + & + & - & - & + \\
\hline 2 & + & + & & & + \\
\hline 3 & + & + & No sample & + & + \\
\hline 4 & + & + & + & - & - \\
\hline 5 & + & + & - & & + \\
\hline 6 & + & + & & & - \\
\hline 7 & + & + & + & - & - \\
\hline 8 & - & + & No sample & & - \\
\hline 9 & - & + & - & & + \\
\hline 10 & - & + & & & - \\
\hline 11 & - & + & & & + \\
\hline 12 & + & - & & & + \\
\hline 13 & + & + & & & + \\
\hline 14 & + & + & & & + \\
\hline 15 & + & - & & + & - \\
\hline 16 & + & + & & & + \\
\hline 17 & + & + & & & + \\
\hline 18 & + & + & & & + \\
\hline
\end{tabular}

clinical manifestation of mycobacteriosis ranged between 3 and 5 months. In two cases, falcons were diagnosed with mycobacteriosis at the time of their first presentation at the Abu Dhabi Falcon Hospital. Therefore, the time of disease manifestation is not known. One of these two falcons was also tested positive for A. baumannii.

Cutaneous lesions of the diseased falcons were found only as localized lesions on both body walls ranging from the lower thoracical part to the abdominal areas as well as on the inside of left and right thighs. The sizes were variable and ranged from $0.5 \mathrm{~mm}$ up to $5 \mathrm{~cm}$. The yellowish lesions were of firm, leathery-like consistency. In contrast, in quails firm, pale-colored nodes of different sizes could be found from the midcervical region up to the thoracic inlet [19].

Mycobacteriosis cannot be easily identified by hematological changes or clinical symptoms until the disease reaches more advanced stages [8]. In our study, the hematological changes showed unified patterns with strong anemia, high white blood cell counts, heterophilia and strong lymphocytopenia. Furthermore, basophilia was present. Further hematological changes indicating a mycobacteriosis are presence of low albumin and low total protein levels [20], which however, could not be supported by the findings of our study. In our study, albumin and total protein levels were slightly elevated. On the other hand, changes in hematological parameters have been described as nonspecific [21]. In falcons, severe bacterial of fungal infections like aspergillosis and pseudomoniasis can cause highly elevated WBC and heterophilia associated with lymphocytopenia. As in our study $39 \%$ of the falcons were not diagnosed with any other disease than mycobacteriosis, the blood parameter changes could not be caused by another underlying disease. However, the hematological blood picture of the diseased falcons in our study showed very distinctive change patterns, thus, indicating a mycobacteriosis. In all performed acid-fast bacilli stains, bacilli were clearly identified which is highly indicative for a mycobacteriosis and got confirmed through the PCR results.

A difficulty in avian mycobacteriosis identification is the fact that the bacterium gets mainly shed in the advanced stages of the disease, but not in the early ones [22]. Unsuccessful identification of mycobacterial species despite repeated trials are reported in research [14]. This problem might be related to severe DNA damage during processing [23] which could be an explanation for the difficulties of mycobacterium detection in our study. Another explanation for unsuccessful mycobacterial detection might be the extremely low quantity of mycobacterial DNA in paraffinembedded tissues [23]. Due to the unequal distribution of mycobacteria in tissue samples, this reason might be also applicable to the tissue samples in our study although only fresh and not paraffin-embedded tissues were examined.

Treatment of mycobacteriosis can take up to one year and in successful cases included a combination of different drugs like clarithromycin, ethambutol, rifabutin, and enrofloxacin [7]. Rifampicin is highly efficient in combination with other antimicrobials. It can be used as monotherapy although during the treatment period limitations of its efficiency may be caused through resistances [24]. In our case, rifampicin was used as monotherapy for 45 and 68 days leading to 
the survival of the two only falcons treated. One of them was tested negative repeatedly. Moreover, its skin lesion disappeared completely after gradual regression. At the time of treatment, the diagnosis of A. baumannii infection was not yet established.

The finding of the presence of A. baumannii was completely unexpected. So far, as to the authors' knowledge, no cutaneous mycobacteriosis lesions in animals and birds have been found in association with A. baumannii so far. However, A. baumannii infections cannot only be observed in humans, but also in animals like cats, dogs [25], and horses [26]. Random sampling of a zoological collection in Japan led to the isolation of Acinetobacter baumannii from the feces of wild birds. However, it was not mentioned if any pathological condition of the birds was present [27]. Commercially available microbiology testing systems like Mini-API or Vitek are not successful in the detection of A. baumannii but its identification by ITS sequencing is regarded as a very reliable method [17]. A $2.6 \mathrm{kbp}$ DNA fragment was identified from a multidrug-resistant $A$. baumannii strain in a horse. This cassette structure was identical to that isolated in an unrelated human Acinetobacter strain. As the numbers of isolates in humans carrying the class 1 integrons are on the rise, this might be applicable to animals as well. Therefore, the transmission from human-to-animal or animal-to-human of MDR Acinetobacter spp. seems to be possible [28].

In the regular monthly facility screening of the Abu Dhabi Falcon Hospital, A. baumannii was never detected throughout the years 2006, 2007, and 2008-except in December 2007. In the facility screening of December 29th 2007, A. baumannii was identified on the exam room work table, adjacent work bench and computer as well as one glove used for holding falcons. This clearly indicates that this pathogen was not present in the hospital 17 month before the diseased falcons were diagnosed. Moreover, after immediate cleaning up of the affected areas, A. baumannii was not detected again until August 2008. Due to the fact that one falcon of this study was presented in the Abu Dhabi Falcon Hospital for examination on December 27th, 2007, these findings strongly indicate that the infected falcon had shed the bacteria when arriving at the hospital. The contamination came therefore presumably through handling of this falcon. Moreover, in one falcon that was presented for the first time at the Abu Dhabi Falcon Hospital, A. baumannii was isolated from a cutaneous lesion. This leads to the assumption that a nosocomial infection of the falcons in our study does not seem likely although nosocomial A. baumannii infections are frequently found in hospitals [4]. The route of transmission of mycobacteriosis and $A$. baumannii in the falcons of this study remains unclear due to the fact that they come from different breeders, owners and are kept in different places.

It seems likely that the falcons became infected with A. baumannii through contaminated wild birds, possibly through their feces [27], which they might have caught while hunting. However, it remains unclear to what extent wild birds are infected with $A$. baumannii and what might be the likelihood of a possible interspecies transmission. Further research is needed in this subject. Moreover, the findings of this study raise the question if a human-to-birds or birds-tohuman transmission of $A$. baumannii exists which requires further investigation.

\section{References}

[1] P. C. Schreckenberger, M. I. Daneshvar, R. S. Weyant, and D. G. Hollis, "Acinetobacter, Achromobacter, Chryseobacterium, Moxarella, and other nonfermentive gram-negative rods," in Manual of Clinical Microbiology, P. R. Murray, Ed., pp. 749779, ASM Press, Washington, DC, USA, 8th edition, 2003.

[2] A. Jawad, H. Seifert, A. M. Snelling, J. Heritage, and P. M. Hawkey, "Survival of Acinetobacter baumannii on dry surfaces: comparison of outbreak and sporadic isolates," Journal of Clinical Microbiology, vol. 36, no. 7, pp. 1938-1941, 1998.

[3] P. Baumann, "Isolation of Acinetobacter from soil and water," Journal of Bacteriology, vol. 96, no. 1, pp. 39-42, 1968.

[4] D. Villers, E. Espaze, M. Coste-Burel et al., "Nosocomial Acinetobacter baumannii infections: microbiological and clinical epidemiology," Annals of Internal Medicine, vol. 129, no. 3, pp. 182-189, 1998.

[5] M. G. Smith, T. A. Gianoulis, S. Pukatzki et al., "New insights into Acinetobacter baumannii pathogenesis revealed by highdensity pyrosequencing and transposon mutagenesis," Genes and Development, vol. 21, no. 5, pp. 601-614, 2007.

[6] L. A. Tell, K. Gilardi, M. Ziccardi, and D. Phalen, "A multifaceted investigation into the diagnosis of mycobacterial infections in birds," in Proceedings of the Annual Conference of the Association of Avian Veterinarians, pp. 61-63, Monterey, Calif, USA, 2002.

[7] A. M. Lennox, "Successful treatment of mycobacteriosis in three psittacine birds," in Proceedings of the Annual Conference of the Association of Avian Veterinarians, pp. 61-63, Monterey, Calif, USA, 2002.

[8] L. A. Tell, L. Woods, and R. L. Cromie, "Mycobacteriosis in birds," Revue Scientifique et Technique de l'Office International des Epizooties, vol. 20, no. 1, pp. 180-203, 2001.

[9] G. E. Pfyffer, B. A. Brown-Elliott, and R. J. Wallace, "Mycobacterium: general characteristics, isolation and staining procedures," in Manual of Clinical Microbiology, P. R. Murray, Ed., pp. 532-559, ASM Press, Washington, DC, USA, 8th edition, 2003.

[10] R. Gopinatham, D. Pandit, J. Joshi, H. Jerajani, and M. Mathur, "Clinical and morphological variants of cutaneous tuberculosis and its relation to mycobacterium species," Indian Journal of Dermatology, vol. 19, pp. 193-196, 2001.

[11] J. H. Gill, "Avian skin diseases," in Veterinary Clinics of North America. Exotic Animal Practice. Avian Pet Medicine, A. E. Rupley, Ed., pp. 145-166, Elsevier Sauders, Amsterdam, The Netherlands, 2005.

[12] L. Ferrer, A. Ramis, J. Fernández, and N. Majó, "Granulomatous dermatitis caused by Mycobacterium genavense in two psittacine birds," Veterinary Dermatology, vol. 8, no. 3, pp. 213-219, 1997.

[13] M. G. Muller, A. George, and A. T. Mannil, "Hematological values of Gyr hybrid falcons," in Proceedings of the 8th European Association of Avian Veterinarians Conference, pp. 77-84, Arles, France, April 2005.

[14] G. Manarolla, E. Liandris, G. Pisoni et al., "Avian mycobacteriosis in companion birds: 20-year survey," Veterinary Microbiology, vol. 133, no. 4, pp. 323-327, 2009. 
[15] S. F. Altschul, T. L. Madden, A. A. Schäffer et al., "Gapped BLAST and PSI-BLAST: a new generation of protein database search programs," Nucleic Acids Research, vol. 25, no. 17, pp. 3389-3402, 1997.

[16] M. Blaschitz, M. Narodoslavsky-Gföller, M. Kanzler, J. Walochnik, and G. Stanek, "Borrelia burgdorferi sensu lato genospecies in questing Ixodes ricinus ticks in Austria," International Journal of Medical Microbiology, vol. 298, supplement 1, pp. 168-176, 2008.

[17] H. C. Chang, Y. F. Wei, L. Dijkshoorn, M. Vaneechoutte, C. T. Tang, and T. C. Chang, "Species-level identification of isolates of the Acinetobacter calcoaceticus-Acinetobacter baumannii complex by sequence analysis of the 16S-23S rRNA gene spacer region," Journal of Clinical Microbiology, vol. 43, no. 4, pp. 1632-1639, 2005.

[18] M. G. Muller, Practical Handbook of Falcon Husbandry and Medicine, Nova, New York, NY, USA, 2009.

[19] L. A. Tell, L. Woods, J. Foley, M. L. Needham, and R. L. Walker, "A model of avian mycobacteriosis: clinical and histopathologic findings in Japanese quail (Coturnix coturnix japonica) intravenously inoculated with Mycobacterium avium," Avian Diseases, vol. 47, no. 2, pp. 433-443, 2003.

[20] K. L. Rosenthal, "Avian proteins disorders," in Laboratory Medicine. Avian and Exotic Pets, A. M. Fudge, Ed., pp. 171173, W.B. Saunders, Philadelhia, Pa, USA, 2000.

[21] C. Cray, A. Crim, and S. Clubb, "Serological and molecular diagnosis of mycobacteriosis," in Proceedings of the Annual Conference of the Association of Avian Veterinarians, pp. 83-85, Orlando, Fla, USA, 2001.

[22] L. A. Tell, J. Foley, M. L. Needham, and R. L. Walker, "Diagnosis of avian mycobacteriosis: comparison of culture, acid-fast stains, and polymerase chain reaction for the identification of Mycobacterium avium in experimentally inoculated Japanese quail (Coturnix coturnix Japonensis)," Avian Diseases, vol. 47, no. 2, pp. 444-452, 2003.

[23] M. Srinivasan, D. Sedmak, and S. Jewell, "Effect of fixatives and tissue processing on the content and integrity of nucleic acids," American Journal of Pathology, vol. 161, no. 6, pp. 19611971, 2002.

[24] M. E. Pachón-Ibáñez, F. Fernández-Cuenca, F. Docobo-Pérez, J. Pachón, and A. Pascual, "Prevention of rifampicin resistance in Acinetobacter baumannii in an experimental pneumonia murine model, using rifampicin associated with imipenem or sulbactam," Journal of Antimicrobial Chemotherapy, vol. 58, no. 3, pp. 689-692, 2006.

[25] T. Francey, F. Gaschen, J. Nicolet, and A. P. Burnens, "The role of Acinetobacter baumannii as a nosocomial pathogen for dogs and cats in an intensive care unit," Journal of Veterinary Internal Medicine, vol. 14, no. 2, pp. 177-183, 2000.

[26] M. Vaneechoutte, L. A. Devriese, L. Dijkshoorn et al., “Acinetobacter baumannii-infected vascular catheters collected from horses in an equine clinic," Journal of Clinical Microbiology, vol. 38, no. 11, pp. 4280-4281, 2000.

[27] A. M. Ahmed, Y. Motoi, M. Sato et al., "Zoo animals as reservoirs of gram-negative bacteria harboring integrons and antimicrobial resistance genes," Applied and Environmental Microbiology, vol. 73, no. 20, pp. 6686-6690, 2007.

[28] Y. Abbott, R. O'Mahony, N. Leonard et al., "Characterization of a $2.6 \mathrm{kbp}$ variable region within a class 1 integron found in an Acinetobacter baumannii strain isolated from a horse," Journal of Antimicrobial Chemotherapy, vol. 55, no. 3, pp. 367370, 2005. 

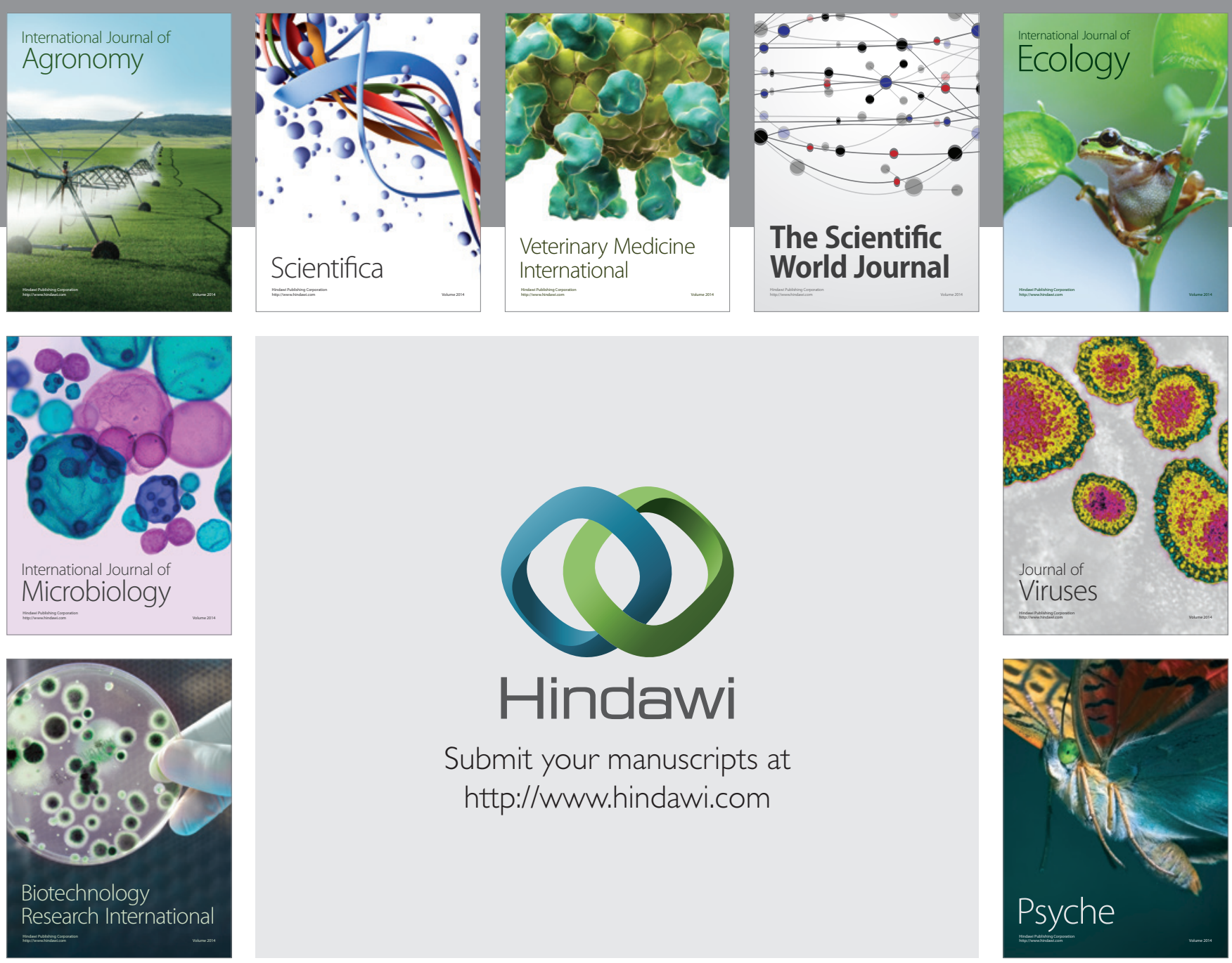

Submit your manuscripts at

http://www.hindawi.com
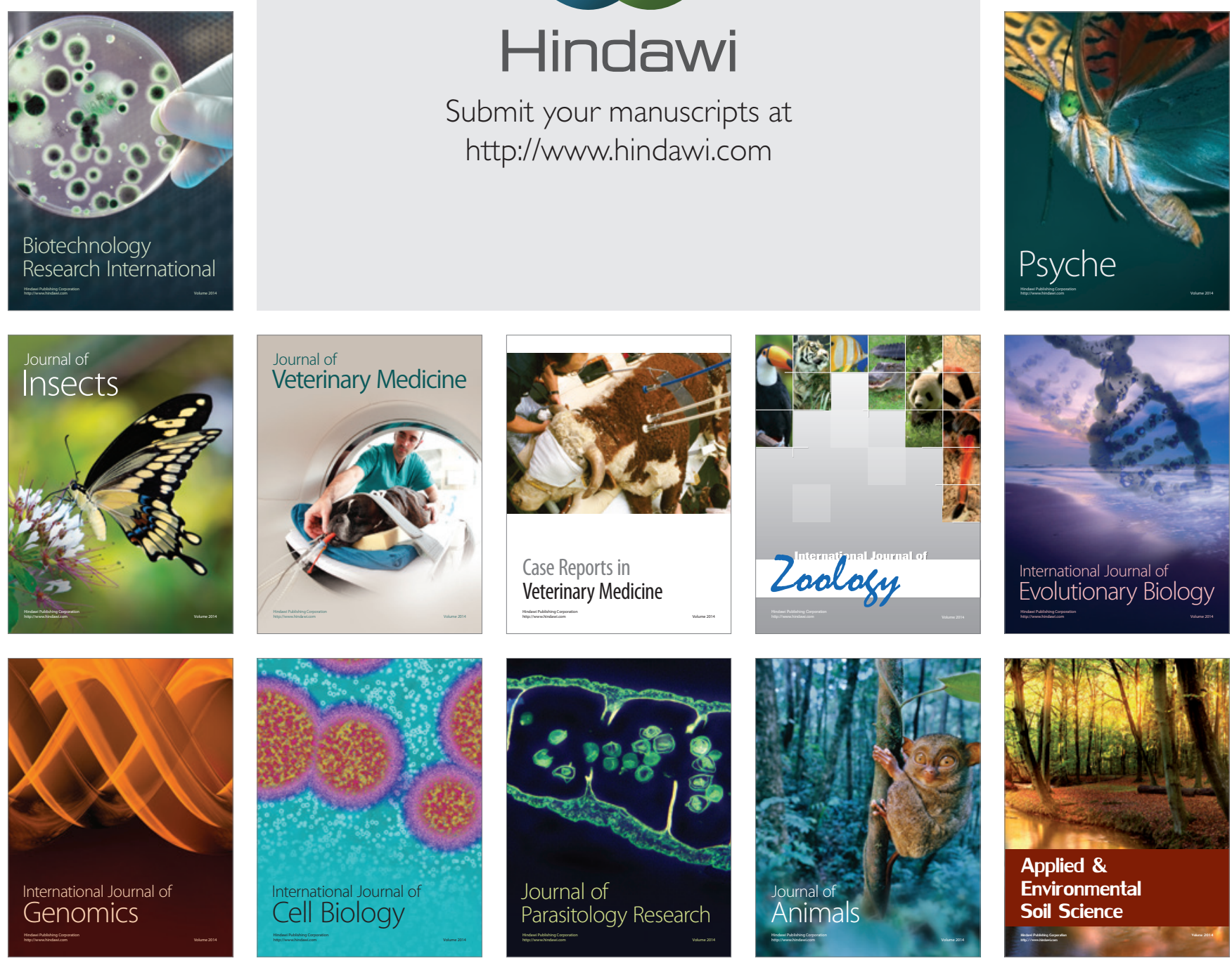